\title{
Pricing of Sovereign Credit Risk: Evidence from Advanced Economies During the Financial Crisis
}

C. Emre Alper, Lorenzo Forni and Marc Gerard 


\title{
IMF Working Paper
}

Fiscal Affairs Department

\section{Pricing of Sovereign Credit Risk: Evidence from Advanced Economies during the Financial Crisis ${ }^{1}$}

\author{
Prepared by C. Emre Alper, Lorenzo Forni and Marc Gerard
}

Authorized for distribution by Martine Guerguil

January 2012

\begin{abstract}
We investigate the pricing of sovereign credit risk over the period 2008-2010 for selected advanced economies by examining two widely-used indicators: sovereign credit default swap (CDS) and relative asset swap (RAS) spreads. Cointegration analysis suggests the existence of an imperfect market arbitrage relationship between the cash (RAS) and the derivatives (CDS) markets, with price discovery taking place in the latter. Likewise, panel regressions aimed at uncovering the fundamental drivers of the two indicators show that the CDS market, although less liquid, has provided a better signal for sovereign credit risk during the period of the recent financial crisis.
\end{abstract}

JEL Classification Numbers: E43, E62, G12

Keywords: advanced economies; sovereign spreads; fiscal risks.

Author’s E-Mail Address: EAlper@imf.org; LForni@imf.org; MGerard@imf.org

\section{This Working Paper should not be reported as representing the views of the IMF.}

The views expressed in this Working Paper are those of the author(s) and do not necessarily represent those of the IMF or IMF policy. Working Papers describe research in progress by the author(s) and are published to elicit comments and to further debate.

\footnotetext{
${ }^{1}$ The authors are indebted to Jennie Bai, Joe di Censo, Marco Naldi, and Jari Stehn, for discussions and comments, as well as Daniel Leigh for preliminary estimations of the fundamental determinants of the CDS and RAS spreads. We would also like to thank the participants of the IMF FAD seminar series (Washington, December 2011).
} 


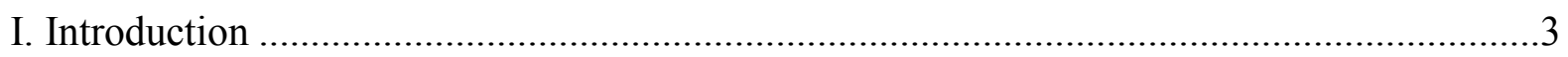

II. Dynamic Relationships between CDS and RAS Spreads ..........................................

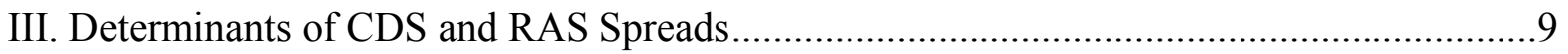

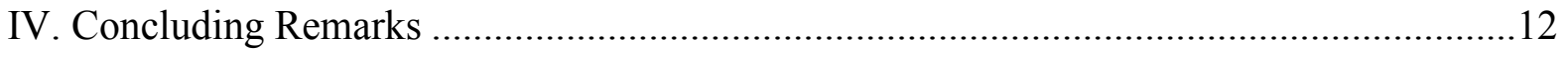

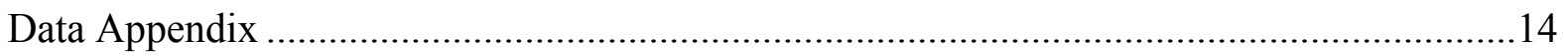

Tables

1. Panel and Individual Unit Root Test Results on the Basis (CDS-RAS)...........................19

2. Individual Cointegration Test and Error-correction Model Estimation Results for CDS and

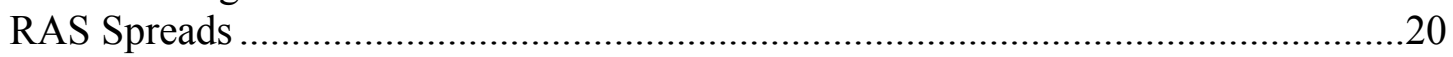

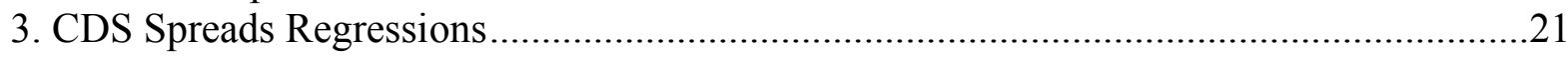

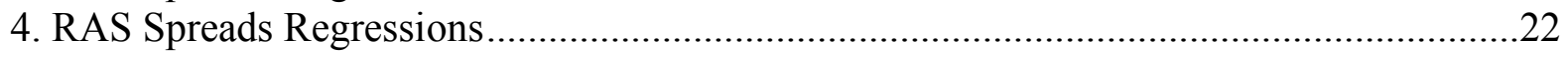

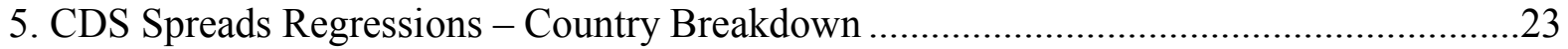

6. RAS Spreads Regressions--Country Breakdown........................................................24

Figures

1. CDS Gross Notional Outstanding Amounts as a Share of Total Public Debt: Selected Countries over the Period 2008-11 ............................................................................. 15

2. CDS and RAS Spread Developments .................................................................... 16

3. Expected one year ahead Primary Deficit and CDS/RAS Spreads - Large Advanced

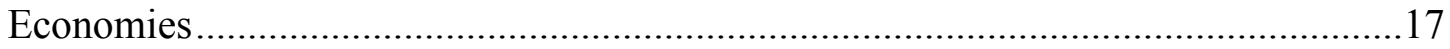

4. Expected one year ahead Primary Deficit and CDS/RAS Spreads - Selected ...................18

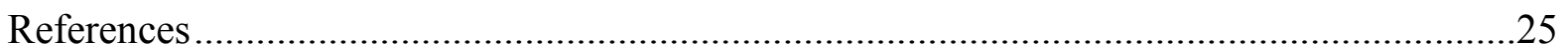




\section{INTRODUCTION}

The recent financial crisis has put significant strains on the fiscal positions of advanced economies. Budget deficits have deteriorated substantially and the government financing needs of many countries have increased to unprecedented levels. In this context, financial markets have put under increased scrutiny the fiscal stance of advanced sovereign issuers, particularly in the euro area.

This paper considers recent developments in two widely monitored market indicators of sovereign risk, credit default swaps (CDS) and relative asset swap spreads (RAS), in order to assess whether they provide consistent signals of market participants' pricing of sovereign risk and whether they are explained by the same set of fundamentals. The analysis focuses on advanced economies during the recent financial crisis i.e. 2008-2010.

A sovereign CDS is a bilateral contract whereby a protection buyer agrees to pay a periodic fee or "premium" in exchange for a payment by the protection seller in the case of a predefined credit event (such as a moratorium, a restructuring or an outright default) affecting a reference sovereign bond. The market price of the premium, quoted in percent of the notional amount and referred to as the CDS spread, is therefore an indication of the perceived sovereign risk. A RAS spread measures the difference between a benchmark government bond yield and the fixed-rate arm of an interest rate swap in the domestic currency with the same maturity. The fixed-rate arm of an interest rate swap may be used to proxy the risk-free rate needed to compute bond spreads, as an alternative to US Treasury or German bond yields. The interest rate swap market is very liquid with all major investment banks acting as market makers and quoting swaps in all the most significant currencies. Therefore, although not invariant over time, these contracts embed a counterparty risk that can be deemed similar across different currencies. Thus, the use of RAS spreads allows meaningful comparisons across countries.

In theory, RAS and CDS spreads written on the same sovereign bond should be equal, because both spreads are meant to cover investors' losses in case a credit event materializes. The return from selling CDS protection can be obtained by shorting a par fixed coupon bond on the reference entity for the same maturity, and investing the proceeds in a par fixed coupon risk-free security. Thus, the no-arbitrage condition across the cash and the derivatives markets implies (for country $i$ and period $t$ ):

$$
\rho_{i, t}=c_{i, t}-r_{i, t}
$$

where $\rho$ denotes the CDS premium, $c$ the fixed coupon attached to the sovereign bond with the same maturity and $r$ the risk-free rate. In case $\rho>c-r$, an investor could make a profit by selling a CDS contract (at the spread $\rho$ ), shorting a bond on the sovereign (with coupon $c$ ) and buying a risk-free security in the cash market (yielding $r$ ). In case $\rho<c-r$, the investor 
could profit from purchasing protection through a CDS contract, buying the sovereign bond and shorting a risk-free security.

In practice, this equivalence and the related no-arbitrage condition is likely not to strictly hold, but to undergo significant distortions. On the one hand, premia paid on specific CDS contracts tend to be affected by institutional factors such as specific settlement procedures (by cash or in kind, with or without 'cheapest-to-deliver' options ${ }^{2}$ ) and varying definitions of credit events across countries (restructuring or outright defaults). On the other, regulatory constraints may apply in the government bond market, most notably preventing the shortselling of bonds. Furthermore, the relative level of both spreads may be influenced by liquidity considerations, as the derivatives market for some sovereign is not very liquid. ${ }^{3}$ Thus, the consistency of sovereign risk pricing across both markets may be undermined by substantial deviations from the theoretical one-to-one arbitrage relationship. ${ }^{4}$

One should expect, however, that the potential for profitable arbitrage across the cash and the derivatives markets would limit volatility in the basis, i.e. the difference between CDS and RAS spreads over time. There should be some patterns of co-movement between CDS and RAS spreads, as both the CDS and RAS spread changes should be driven by similar fundamental factors. To investigate this issue, we first perform unit root tests on the basis (a non-stationary basis would be difficult to reconcile with the no-arbitrage condition), followed by broader cointegration analysis on CDS and RAS spreads. Next, using panel regressions, we investigate the determinants of CDS and RAS spreads, including market analysts' expectations of fundamental variables rather than ex-post values. We use a sample of 21 advanced economies over the years 2008-2010, focusing on the period of the recent financial crisis. We don't consider the most recent period as spread for certain countries have been extremely volatile, specifically for the three European countries currently under programs. Similarly, we start from the beginning of 2008 as liquidity of the CDS market has improved only recently (see Figure 1) and before the crisis there has been very little movement in advanced economies' spreads.

\footnotetext{
${ }^{2}$ When the sovereign has several outstanding bonds, a CDS contract may include a 'cheapest-to-deliver' option whereby the protection buyer is given the opportunity to choose which title to deliver to the protection seller in exchange of payment.

${ }^{3}$ The cash market is much more liquid that the CDS market for most sovereigns (see BIS 2010a). In recent years, however, outstanding CDS amounts have increased significantly, especially for those European economies under market pressure (see BIS 2010b). For a review of institutional aspects and liquidity developments of the CDS market, see, among others, ECB (2009).

${ }^{4}$ In fact, over the financial crisis, the basis, that is the difference between CDS and RAS spreads, has been extremely volatile.
} 
Our results can be summarized as follows. Unit root tests on the basis and cointegration analysis on both indicators suggest that the no-arbitrage condition between the cash and the derivatives markets holds in a limited number of countries, notably Greece, Ireland and Spain. When this is the case, evidence suggests that CDS spreads have played a leading role in the process of price discovery. Panel regressions indicate that variables related to fiscal sustainability explain only a limited share of the variation of CDS and RAS spreads, whereas domestic financial and global factors have higher explanatory power. Furthermore, RAS spreads tend to be weakly related to fundamentals, whereas CDS spreads seem to better capture indicators of increased fiscal risks. Overall, these results suggest that during and in the aftermath of the financial crisis, CDS spreads may have played a more direct role in pricing sovereign credit risk than RAS spreads, mainly because they have proven more correlated with news about fundamentals.

The paper is organized as follows. Section II describes the patterns of co-movements between CDS and RAS. Section III relates spreads to fundamentals. Section IV concludes.

\section{DYNAMIC RELATIONSHIPS BETWEEN CDS AND RAS SPREADS}

Most of the empirical literature on the links between bond and CDS spreads has focused on the corporate sector. While the absence of durable, profitable arbitrage opportunities between the cash and the derivatives market is usually verified, market inefficiencies are found to matter in the short run. In this respect, it is usually found that CDS spreads 'lead' over bond spreads to restore equilibrium (Zhu, 2004; Norden and Weber, 2004; and Blanco et al., 2005). In the case of sovereign entities, studies have brought mixed results, notably in the case of emerging economies, whereby the existence of co-movements between CDS spreads and other proxies for bond spreads is generally verified, but the causal relationships between the variables appear less clear-cut (Chang-Lau and Kim (2004); Ammer and Cai (2007); Aktug et al., (2008) Fontana and Scheicher (2010); Coudert and Gex (2011)).

In the current paper, for each economy in the sample, we investigate the existence, form and robustness of a possible arbitrage relationship between the CDS and RAS spread series by, first, examining the stationarity of the basis, and second, estimating and testing vector errorcorrection models (VECM) on both series. We use daily market data on 10-year sovereign bond yields and fixed interest rates in interest rate swaps to calculate RAS spreads, and 5year sovereign CDS spreads, provided by the Datastream and Markit databases, respectively, over the period January 2008-January 2011. While the time span may be short, series of similar or even shorter lengths have been used in cointegration analysis applied to daily financial series, both for corporate (Blanco, Brennan and Marsh (2004); Zhu (2004); Norden and Weber (2004)) and, more recently, for sovereign issuers (Fontana and Scheicher (2010); Coudert and Gex (2011)). The choice to compute spreads of different maturities has been

dictated by the concern to use the most liquid market for each category of instrument. Insofar as they reflect structural market characteristics, the distortions that are introduced in the arbitrage relationship can be expected to remain constant over time. The analysis is 
performed for Australia, Austria, Belgium, Denmark, Finland, France, Germany, Greece, Ireland, Italy, Japan, the Netherlands, Norway, Portugal, Spain, Sweden, the UK and the US. ${ }^{5}$ Figure 2 reports a plot of the data.

\section{Methodology}

The methodology consists of three steps.

First, we test for the stationarity of both series for each economy, selecting lag lengths using a step-down procedure and selection criteria. For each sovereign, the CDS and RAS spread series have to be integrated of order one for the analysis to proceed. Under the assumption of cointegration between series found to be integrated of order one (i.e. residuals are covariance stationary), we also perform Granger-causality tests to preliminary assess possible causal links among these (not reported here).

Next, we perform panel and individual unit root tests on the basis (the difference between CDS and RAS spreads), to investigate the prevalence of the no-arbitrage condition in its 'strict form'. Evidence in favor of stationarity would indicate that there exists a stable relationship between both indicators by which they co-move one-to-one in response to shocks.

Finally, we consider the possibility of more flexible forms of co-movement, whereby the series would be linked over time by a stable relationship, but with deviations from the strict, one-to-one version of the no-arbitrage condition. For each country $i$, this is investigated by performing trace tests and estimations of various specifications of the following functional form:

$\Delta X_{i, t}=\alpha \beta^{\prime} Z_{1, i, t}+\Psi Z_{2, i, t}+\varepsilon_{i, t}$

with: $Z_{1, i, t}=\left(X_{i, t-1}, D_{i, t}\right)^{\prime}$ and $Z_{2, i, t}=\left(\sum_{j=1}^{n_{i}} \Delta X_{i, t-j}, C_{i, t}\right)^{\prime}$

where $X$ contains the CDS and RAS spreads, $D$ is a vector of deterministic elements which may include a time trend and/or a constant restricted to the cointegrating vector and $C$ is a general deterministic term in the error-correction term. In equation (1), the number of lags is country-specific, and determined by a step-down procedure based on likelihood ratio tests and information criteria (relying on the Schwartz criterion in case of conflicting outcomes), ensuring that the residuals are Gaussian white noises. The slope coefficient $\beta$ measures the accuracy of the no-arbitrage relationship, with a coefficient of 1 indicating that series co-

\footnotetext{
${ }^{5}$ Canada did not, until recently, have a CDS market, and Korea still does not have any. Also, the series for New Zealand and Switzerland exhibit irregularities. Thus, these four countries have been excluded from the sample.
} 
move by the same magnitude over time, while lower value would signal structural discrepancies between markets. The 'speed-of-adjustment' vector $\alpha$ captures the way in which each variable adjusts in case of deviations from the cointegrating relationship. Following common practice in the financial econometric literature, we interpret the absence of any adjustment by a variable as signaling that this variable is actually 'leading' in the process of price discovery (i.e. is the most 'weakly exogenous'), since the bulk of the subsequent adjustment has to fall on the other variable. As RAS spreads have been used for normalization, $\alpha_{R A S}$ needs to be negative and significant or $\alpha_{C D S}$ to be positive and significant, or both, for an EC mechanism to be detected.

\section{Results}

The main results, which can be found in Tables 1 and 2, can be summarized as follows.

Both indicators appear to be nonstationary for all advanced economies in the sample. Individual unit root tests indicate that CDS and RAS spread series are integrated of order one over the sample period in all advanced economies. The null hypothesis of a unit root can only be rejected at the 10 percent level for the RAS spread of Japan and at the 5 percent level for Norway.

LLC and IPS panel unit root tests performed on the basis point to some cointegration across our sample of advanced economies, even when controlling for cross-sectional dependence among series (Table 1). Besides, country-specific ADF-tests on the stationarity of the basis indicate the existence of a stable relationship for 6 countries: Greece, Ireland, Italy, Portugal, Spain and the US. Yet caution is warranted in interpreting these results, as they do not preclude the prevalence of a less restricted version of the no-arbitrage relationship. Indeed, over the crisis, co-movements of CDS and RAS spreads may have been characterized by different cointegrating vectors than one (which is the one consistent with the theoretical relationship, strictly interpreted).

As a matter of fact, cointegration analysis on RAS and CDS spreads within a VECM framework provides further evidence on some imperfect arbitrage between the sovereign cash and derivatives markets in most economies (Table 2). Trace test statistics signal the existence of cointegrating vectors in 9 countries at the 5 percent level, especially among euro area economies such as Austria, Greece, Ireland and Spain, as well as Japan and the US, and in 5 other countries at the 10 percent level, including Italy and Belgium. No cointegration relationship is found for France, Germany and Sweden, as well as Portugal (which qualifies the result found on the basis).

In most instances where evidence stands in favor of cointegration, the slope coefficients $\beta$, which measure the magnitude of the relationship linking CDS to RAS spreads over time, appear reasonably close to 1 , typically ranging from 0.7 to 0.9 . This is notably the case in 
Greece, Ireland, Italy and Spain. Slope coefficients tend to be much smaller in bigger economies such as the US and Japan, while the no-arbitrage relationship appears rather weak in the UK and in Norway. Most models necessitate the inclusion of a constant in the cointegrating vector and/or in the error-correction term, signaling the existence of constant gaps in the series. This does not come as a surprise given our initial choice of using differing maturities for both instruments, but the existence of structural pricing discrepancies across markets is also likely to reflect some liquidity premia. Overall, these results point to the existence of co-movement between CDS and RAS spreads for a number of countries, especially those euro area economies which underwent significant fiscal strain, while also indicating that the strict, theoretical one-to-one relationship is rarely satisfied.

For those cases where cointegration exists, evidence suggests that the derivatives market has played a leading role in the process of price discovery, most notably in euro area economies. As a matter of fact, the country-specific 'speed-of-adjustment' coefficients on the RAS variables appear generally significant and negative, whereas the coefficients on the CDS variables are found to be generally insignificant. Thus, short-term pricing discrepancies between both markets appear to have been mostly corrected by adjustments on the cash market, highlighting the leading role of the derivatives market. This is notably the case for Austria, Greece, Italy and Spain, as well as Japan and the US, whereas in Ireland, both prices adjust in reaction to deviations from the equilibrium. Yet in general, speeds of adjustment appear rather slow, with (significant) $\alpha$ coefficients ranging from -0.02 to -0.04 . With daily data, this indicates that markets need about 25 to 50 working days to entirely correct disequilibria after a shock. It is worth stressing, though, that such a long 'return to normal' transition process took place against the backdrop of strong market volatility over the crisis, so that the complete correction of initial disequilibria might have been subject to important disturbances.

Overall, our results indicate the prevalence of various patterns of cointegration relationships between RAS and CDS spread series, highlighting differences between peripheral euro area countries and more advanced economies, while at the same time calling for caution in the interpretation of the results. First, the 'strong' (one-to-one) version of the no-arbitrage relationship appears to be verified for a few peripheral euro area countries such as Greece, Ireland, Portugal, Spain, and Italy. These countries have experienced a significant increase in the CDS market liquidity in recent years (Figure 1). Yet no cointegrating vector could be established for Portugal, which stands out as an outlier in this respect. In other advanced economies such as the US, the UK or Japan, a coefficient on the cointegrating vector significantly below one suggests some significant departure from the theoretical no-arbitrage relationship, which could be due to relatively illiquid CDS markets for these countries. There is no evidence in favor of cointegration for France and Germany. Second, evidence suggests that the derivatives market has played a leading role in the process of sovereign credit risk pricing over the crisis in most economies. It is particularly the case in peripheral euro area economies, where the bulk of the adjustment has taken place on the cash market. This may be 
related to the relative increase in the liquidity of derivatives market in these economies in the recent past.

\section{DETERMINANTS OF CDS AND RAS SPREADS}

As far as the determinants of sovereign spreads are concerned, the previous empirical literature has mainly focused on emerging markets. Regarding the cash market, determinants of the JP Morgan EMBIG index can be grouped in two categories. The first includes countryspecific fundamentals, with proxies generally accounting for fiscal and current account sustainability, as well as financial sector and political stability (Edwards (1984); Min (1998); and Baldacci et al. (2008)). The second category includes global factors or investors' risk appetite, proxied by indicator variables for liquidity conditions such as the U.S. federal funds rate or the VIX index (Arora and Cerisola (2001); IMF (2004, 2006)). For advanced economies sovereign credit risk has been found to be mainly affected by a surge in financial institutions' credit risk in the early phases of the financial crisis, while country-specific factors have weighted relatively more recently in relation to the sovereign risk crisis (Sgherri and Zoli, (2009)). Some papers emphasize the importance of global risk variables (Longstaff et al. (2007)) or co-movement among spreads (Pan and Singleton (2008), Caceres et al. (2010)).

This section analyses the determinants of CDS and RAS spreads during the crisis, assessing in particular how much these spreads are driven by country-specific factors affecting fiscal sustainability (such as debt, deficit and growth) versus global and financial ones (such as global growth, VIX, Central Banks government bonds purchases, banks' balance sheets, money market liquidity conditions). We also analyze whether CDS and RAS spreads for large advanced economies have behaved differently from those of peripheral euro area economies. The goal is to assess to what extent changes in CDS and RAS spreads (for reasons explained below we will focus on changes on a monthly basis) have followed news about fundamentals and whether the two markets have reacted to news in a similar fashion.

Sovereign spreads, as all financial variables, are forward looking variables that depend on expected values of fundamentals. We use Economist Intelligence Unit (EIU) monthly data on market participants' expectations on a variety of economic fundamentals. ${ }^{6}$ Our sample covers the period January 2008-October 2010. In using medium frequency real-time data, we depart from most of the previous literature that used either ex-post and/or annual forecasts (relying for example on OECD Economic Outlook database). The data set includes the following 21 countries: Australia, Austria, Belgium, Canada, Switzerland, Germany, Denmark, Spain, Finland, France, UK, Greece, Ireland, Italy, Japan, Korea, Netherlands, Norway, Portugal, Sweden, and USA.

\footnotetext{
${ }^{6}$ For the restricted sample of G7 countries, similar data are available also from Consensus Forecasts. Using this data instead of EIU for G7 did not provide significant differences.
} 
Figures 3 and 4 plot CDS and RAS spreads together with one-year-ahead expected primary deficit for a selection of large advanced countries (Figure 3 ) and of peripheral euro area ones (Figure 4). They show that during the financial crisis sovereign CDS spreads have increased considerably even in large advanced economies, by about $100 \mathrm{bps}$ from through to peak in the U.S., Japan, Germany and France, and by about 150 and 200 bps, respectively, in the UK and Italy. RAS spreads have increased as well, although by less, as in some countries counterparty risk in the interbank market has increased together with sovereign risk during the height of the financial crisis, leading to an increase in swap rates and bond yields at the same time. The figures show also that the correlation between expected budget deficit and spreads has been limited in most cases, with expected deficit consistently rising at least until the beginning of 2010 while at the same time spreads were decreasing during the first half of 2009.

The regression analysis is based on a model that includes fiscal, financial and global variables, as well as measures to capture large-scale intervention by selected central banks in the long-term segment of the bond markets. We include the primary deficit-to-GDP ratio expected for the current year, lagged (previous year) value of debt-to-GDP and expected oneyear-ahead growth rate. The inclusion of expected deficit for the year and lagged value of debt follows a standard specification in the literature on the effects of fiscal variable on longterm interest rates and it is meant to proxy for expected debt (see, among others, Engen and Hubbard, (2004)). To control for domestic monetary conditions we use the short-term money market rates, while to control for developments in the banking sector balance sheets we compute the domestic banking stock market index relative to the overall domestic stock market index. To control for global factors we use expected one-year-ahead global growth, the VIX index (US Stock Market Volatility Index, which is usually the proxy for global risk aversion) and four dummies, three of which capture the different phases of the global financial crisis and its aftermath (Bear Stearns, Lehman and Greece crisis) and the fourth takes value one in May 2010 when the IMF-EU program for Greece was announced. We also control for large-scale government bond purchases by central banks, as they have had effects on yields and spreads. In particular, we collected data on bond purchases by the Federal Reserve, the Bank of England, the European Central Bank and the Bank of Japan. The Data Appendix at the end of the paper reports the sources and definitions of the variables used.

Following the discussion in the previous section, we focus on the short run and hence the model is estimated in first differences (the variables are defined as differences from the previous month values) by running random effects GLS regressions with robust standard errors. Robust standard errors assume that the observations are independent across groups (countries) but not necessarily within groups. Hausman tests indicate that fixed effects are 
not required and random effects estimation is more efficient ${ }^{7}$. The baseline specification is as follows:

$\Delta \operatorname{Spread}_{i, t}=\beta_{1} \Delta E_{i, t}$ Fiscal $_{i, t}+\beta_{2} \Delta X_{i, t}+\beta_{3} \Delta \operatorname{Spread}_{i, t-1}+u_{i, t}$

The dependent variable is the change in the spread from $t-1$ to $t$ (end of month values). $\Delta E_{i, t}$ Fiscal $_{i, t}$ denotes the change in the expected fiscal variables: primary deficit for the current year ${ }^{8}$ and lagged debt level as a ratio to GDP. $X$ is a vector of all the other mentioned explanatory variables; $u_{i t}$ is the random error. Each equation contains a constant term and a lagged dependent variable to capture possible overshooting. ${ }^{9}$

Tables 3 and 4 report baseline regression results for both CDS and RAS spreads. The tables show that in the CDS spread regressions most included variables are significant, while in those for RAS spreads many variables are not. In particular, CDS spreads decrease when: i) the expected primary deficit is revised downward; ii) expected domestic growth is revised upward; iii) banks' stocks perform relatively better than the national stock market index; iv) global risk aversion moderates; and v) the Federal Reserve engages in large scale purchases of long-term government bonds. Regarding this last variable, it is remarkable that the Federal Reserve's purchases appear to affect CDS spreads, while purchases by other Central Banks are not statistically significant. ${ }^{10}$ Changes in the short-term money market rate are also strongly correlated with CDS spreads. The negative sign suggests that spreads tighten when short-term rates pick up. RAS spreads appear to respond rather differently from CDS to the same set of variables. They share the same reaction to short-term interest rates and to the Federal Reserve's intervention in the long-term bond market, but do not react to fiscal variables, domestic and global growth, global risk aversion and developments in the banks' stock prices, at least during the period under consideration.

In Tables 5 and 6 we split the sample into large advanced economies (Canada, France, Germany, Japan, United States and United Kingdom) and a group of selected euro area ones (Belgium, Greece, Italy, Ireland, Portugal and Spain). For both CDS and RAS regressions the overall fit of the model appears to be moderately better in the case of large advanced

\footnotetext{
${ }^{7}$ The model estimated with fixed effects entails limited differences in the results.

${ }^{8}$ For all months excluding January, we calculate the change in expected primary deficit by subtracting the previous month's value from the current month. For each January, the change in expected current deficit is obtained by subtracting the expected one-year-ahead primary deficit in December from the expected current deficit in January in order to eliminate the calendar effect.

${ }^{9}$ We did not run the Arrelano-Bover or Blundell-Bond estimators (that controls for the endogenous lagged variable) as we would need a short panel, while we have the opposite. We nevertheless removed the lagged dependent variable, without significant changes in the results but for a modest decrease in the overall fit.

${ }^{10}$ See, among others, Doh (2010), Gagnon et al. (2010), and Neely (2010), on the effects of large-scale asset purchases by the Fed.
} 
economies, as probably the selected group of euro area economies came recently under market pressure in a staggered fashion following country specific markets developments.

In the CDS regressions, the primary deficit appears to be significant for the selected group of euro area economies but not for large advanced ones. A second important difference is that central bank interventions (both in the US and other areas) are significant for large advanced countries, while for the selected group of euro area ones, the "domestic" interventions (that are performed by the European Central Bank, ECB) seem not to have had a moderating effect on spreads. This may partly reflect the relatively recent establishment of the ECB's Security Market Program (SMP), specifically aimed at the purchase of euro area government bonds, partly the fact that the ECB releases data on holdings of government securities without providing details on the issuing countries. As expected, banks stock prices have a significant effect on spreads in large advanced economies, while it is less so for smaller euro area countries. Similarly, domestic and global expected growth appears to be more relevant for the selected euro area economies than for large advanced ones.

RAS regressions display a poorer fit compared to the CDS regressions in both subsamples. Additionally, some results for large advanced countries are difficult to interpret, as for example the positive sign on expected domestic growth (suggesting that higher domestic growth leads to an increase in RAS spreads) and banks stock prices (where a decrease in relative banks' stock prices would lead to a decrease in spreads). This latter result supports the observation that in certain instances during the financial crisis increases in counterparty risk have led to a compression in RAS spreads. Finally, for both country subgroups fiscal variables are not significant, while results regarding Central Bank interventions are mixed.

\section{CONCLUding REMARKS}

This paper addressed the linkages and determinants of two widely used indicators of sovereign risk: CDS and RAS spreads. It focused on advanced economies during the recent financial crisis and the sovereign market tensions that followed. It showed strong comovements between both series, especially for those countries that have come under significant market pressure. At the same time, arbitrage distortions have remained pervasive in the biggest economies. This suggests that the liquidity of the derivatives market is of paramount importance for CDS spreads to fully reflect sovereign credit risk. For those economies where the evidence stands in favor of a cointegration relationship, deviations from arbitrage have been long lasting, though in line with results in the literature. Also, CDS spreads were found to anticipate changes in RAS, suggesting that the derivatives market has been leading in the process of pricing sovereign credit risk. Regarding the role of fundamentals, we showed that variables related to fiscal sustainability are able to explain only a limited share of the variation of CDS spreads. Spreads seem to respond more to financial variables (such as domestic banking sector capitalization, short-term liquidity 
conditions, large-scale long-term bond purchases by major central banks) or purely global variables (global growth, global risk aversion, dummies for the different stages of the crisis).

These results refer to a specific group of advanced countries over a short span of time. They suggest that movements in CDS and RAS spreads need to be interpreted with caution. First, while in theory they should be strictly connected, CDS and RAS spreads do not, generally, follow the pattern suggested by the no-arbitrage condition. Moreover, they are affected by several factors, with global and financial considerations playing a dominant role, while at the same time leaving room for a large unexplained component. In general, however, CDS spreads seem to have provided better signals than RAS regarding the market assessment of sovereign risk: over the period covered by the analysis, they have led the process of price discoveries in those countries under market pressure and have been more correlated than RAS to those fundamentals that are expected to affect sovereign risk. 


\section{DATA APPENDIX ${ }^{11}$}

CDS spreads. We use Markit data on 5-years sovereign CDS spreads (monthly averages).

RAS spreads. Difference between benchmark government bond yields and the fixed-rate arm of an interest rate swap in the same currency and of the same maturity (10 years) as the bond (monthly averages).

Expected deficit [Expected Deficit (t)]. Monthly forecasts of expected primary fiscal balance as a share of GDP for the year as reported by the EIU.

Expected debt to GDP ratio [Debt (t-1)]. EIU reports expected debt as a share to GDP for a certain number of past and future years. We use one year lagged value.

Expected domestic growth rate [Expected Growth $(\mathbf{t}+\mathbf{1})]$. EIU one-year-ahead expected real growth rate.

Short-term interest rate [Short Term Rate]. Monthly short-term money market interest rate obtained from International Financial Statistics.

Banks stock prices [Banks Stock Prices]. For each country, we calculate the relative banking sector equity price index. The data is obtained from DataStream. We rebase banking sector equity index and national equity index to $2008=100$ before calculating the ratio.

Expected global growth [Expected Global Growth $(\mathbf{t}+\mathbf{1})]$. Data reported by the EIU for the expected one-year-ahead world growth rate.

VIX [VIX]. The US Stock Market Volatility Index (VIX). We use monthly averages of daily data obtained from DataStream.

Dummy for the different phases of the crisis. We constructed three dummies for the different stages of the financial crisis: Bear Stearns [BStearns dummy] (equals 1 from March 2008 to August 2008, zero otherwise): Lehman [Lehman dummy] (equals 1 from September 2008 to April 2009, zero otherwise): Greece [Greece dummy] (equals 1 from November 2009 to October 2010, zero otherwise).

Dummy for the Greece's Program [Greece Program dummy]. This dummy takes value one in May 2010 when the IMF-EU program for Greece was announced.

Start of the Fed's Government Bond Purchases [FED Bond Purchases Announcement]. This dummy takes value one in March 2009 as the Federal Reserve (FOMC statement) announced the intention to purchases 300 billion in long term Treasuries.

Stock of US Treasury Securities held by the Fed [FED Government Bonds Purchases]. The growth rate of the nominal dollar value of the US Treasury Securities held Outright by the Federal Reserve System starting from February 2009 (on February 2009 the Bank of England begun purchasing Gilts, starting the Quantitative Easing policies). The values so computed are assigned to the US and to all other countries in the sample.

Stock of Government Bonds held by the Fed, Bank of Japan, Bank of England and ECB [Central Banks Government Bonds Purchases]. Same as the above where we replaced US data with national data where available. In particular we have used the nominal growth rate of Gilt holdings by the Bank of England (for both monetary policy purposes and outright) for the UK, the nominal growth rate of government securities held by the Bank of Japan for Japan and the growth rate of ECB nominal holdings (for both monetary operations and under the Securities Market Programs) for all euro area countries. For other countries the variable assumes the same values as for the US.

${ }^{11}$ We report the variable labels reported in the regression tables in square brackets. 
Figure 1. CDS Gross Notional Outstanding Amounts as a Share of Total Public Debt: Selected Countries over the Period 2008-11 (percent)

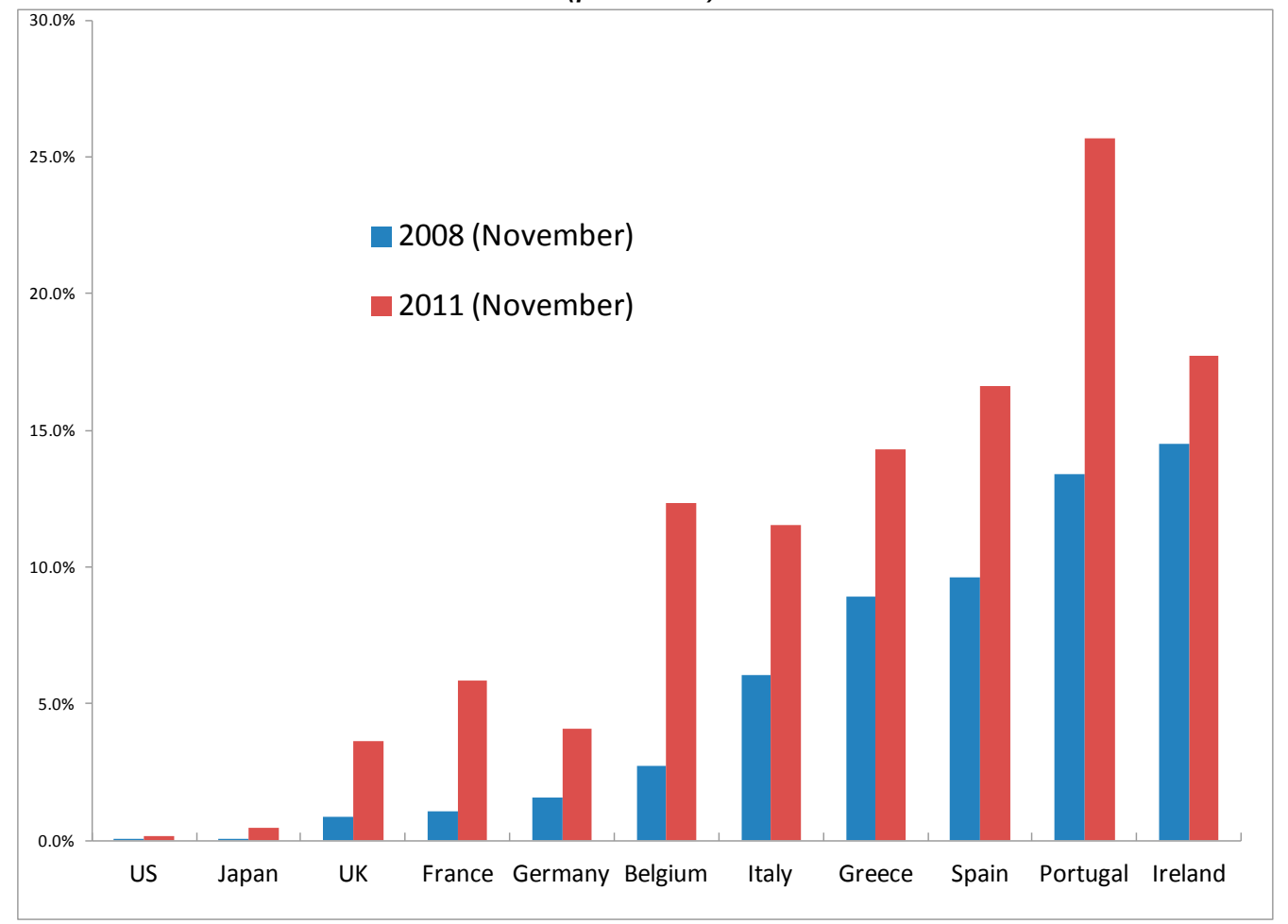

Source: DTCC and staff calculations. 
Figure 2. CDS and RAS Spread Developments
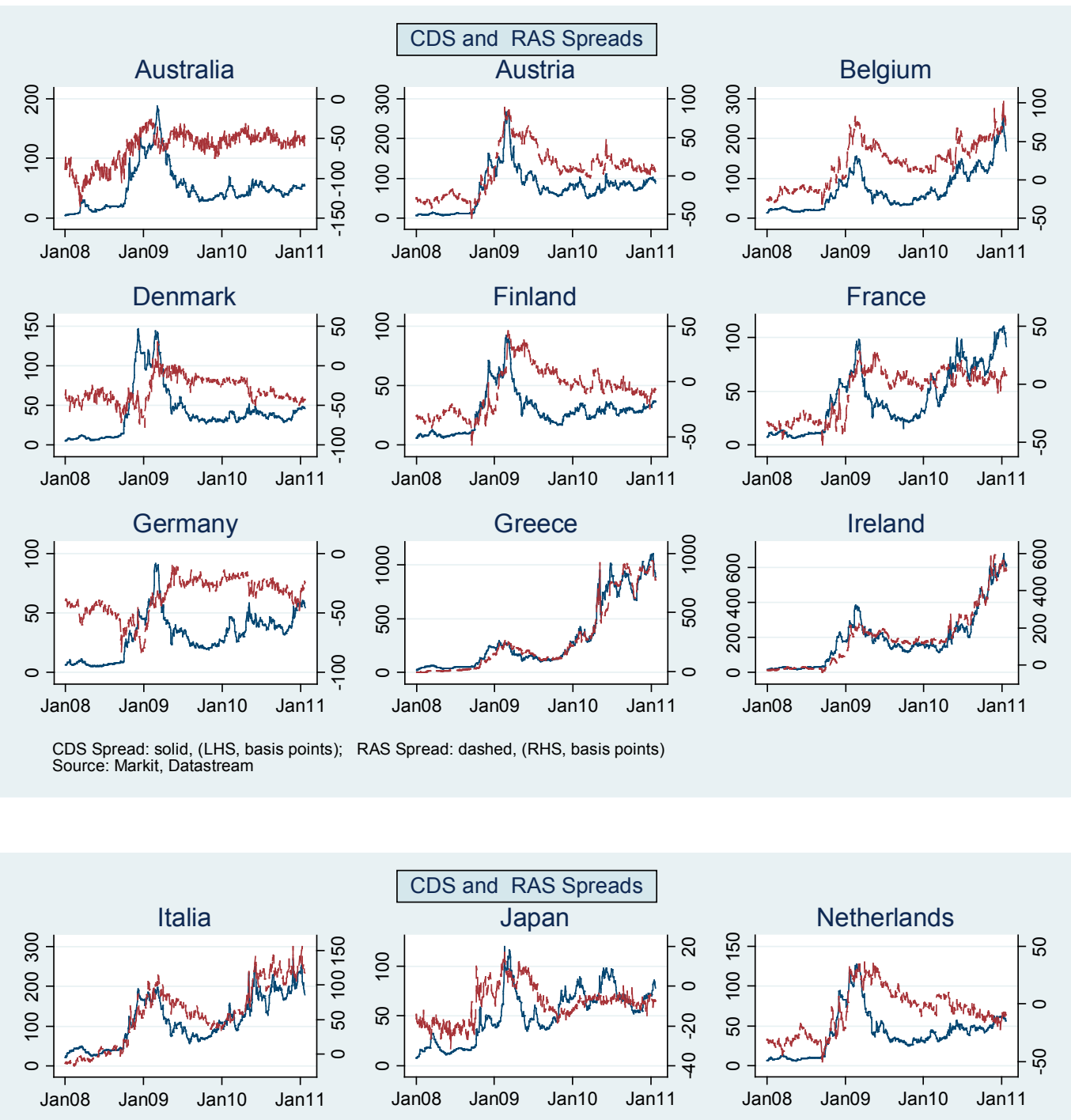

\section{CDS and RAS Spreads}
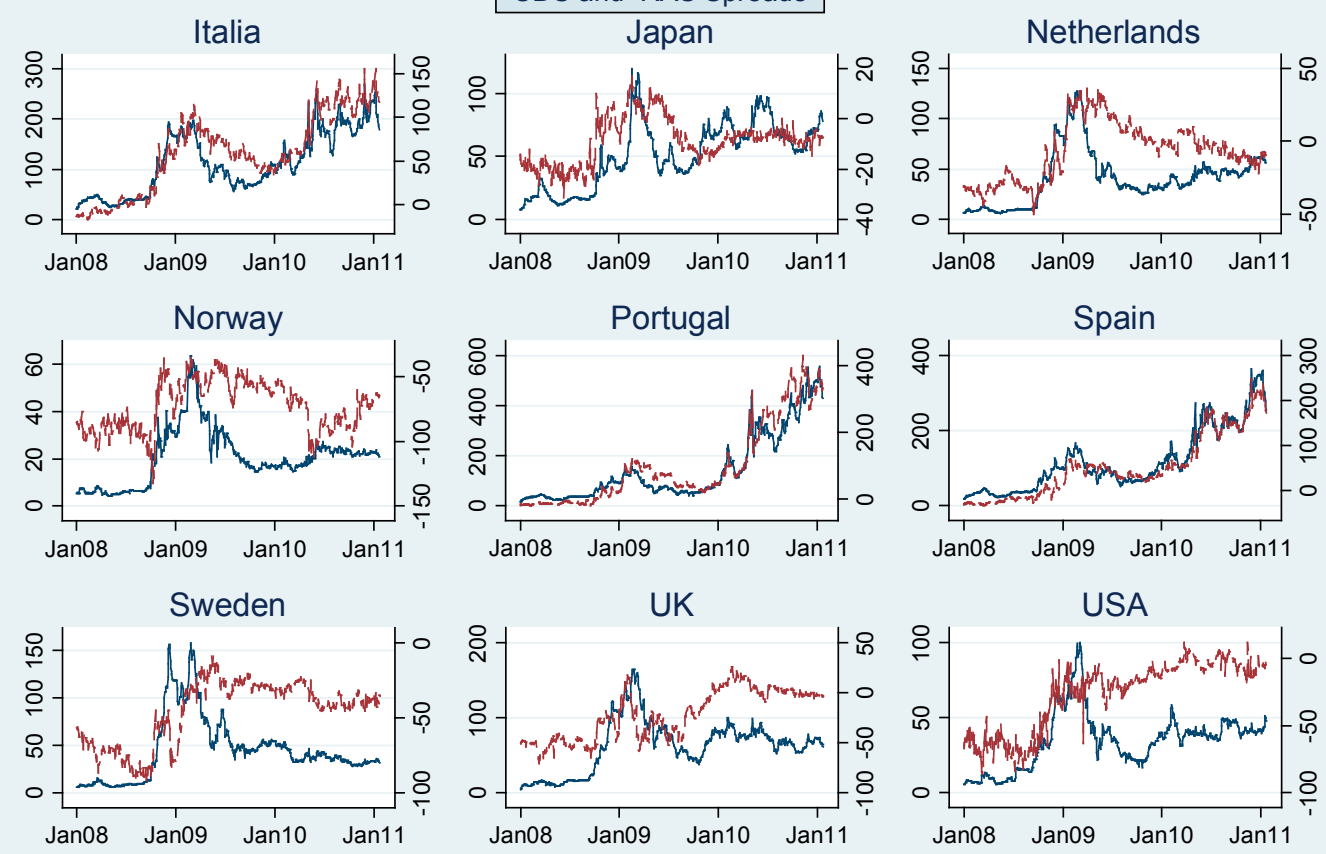

CDS Spread: solid, (LHS, basis points); RAS Spread: dashed, (RHS, basis points) Source: Markit, Datastream 
Figure 3. Expected one year ahead Primary Deficit and CDS/RAS Spreads Large Advanced Economies
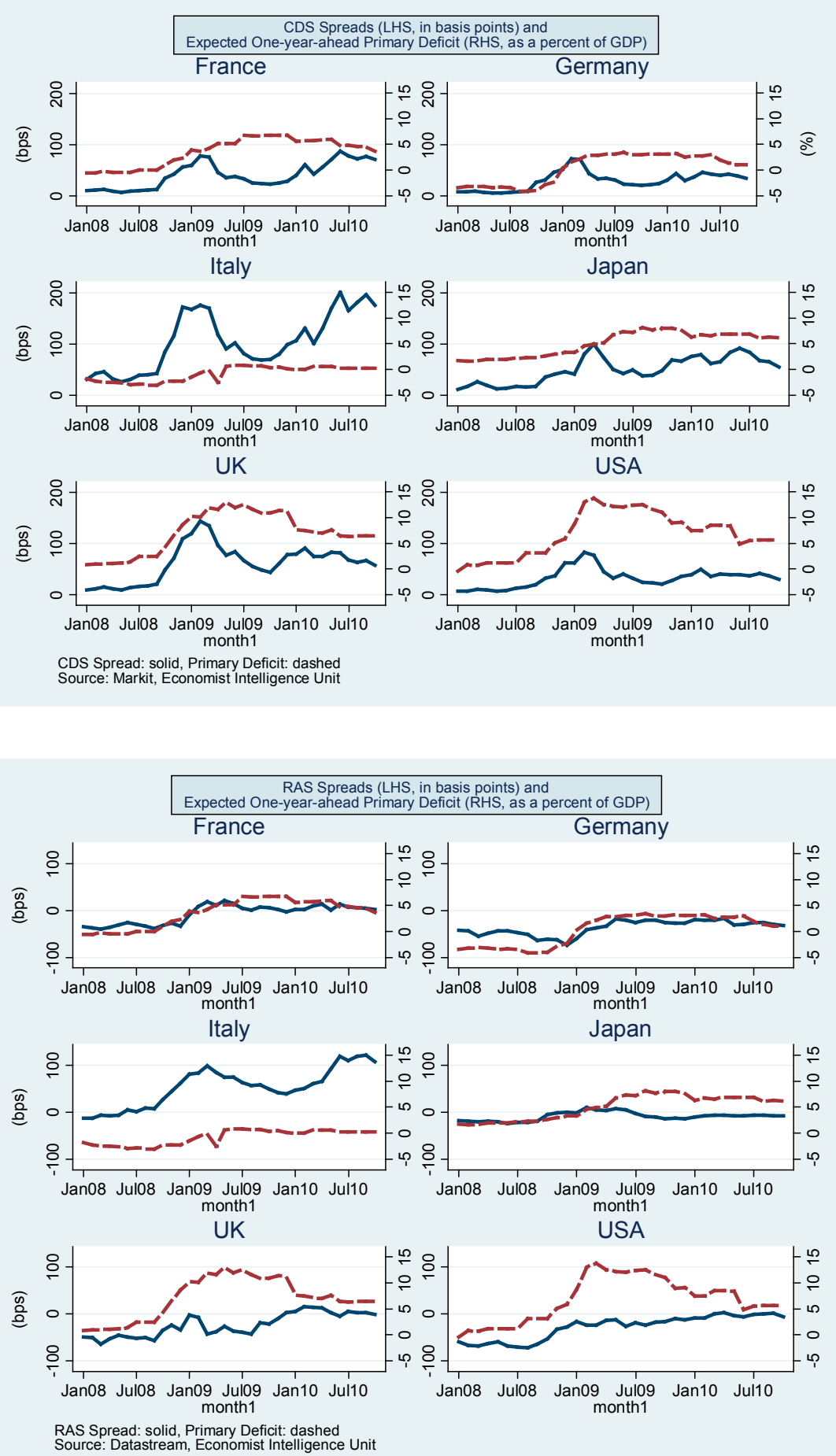
Figure 4. Expected one year ahead Primary Deficit and CDS/RAS Spreads Selected Euro Area Countries
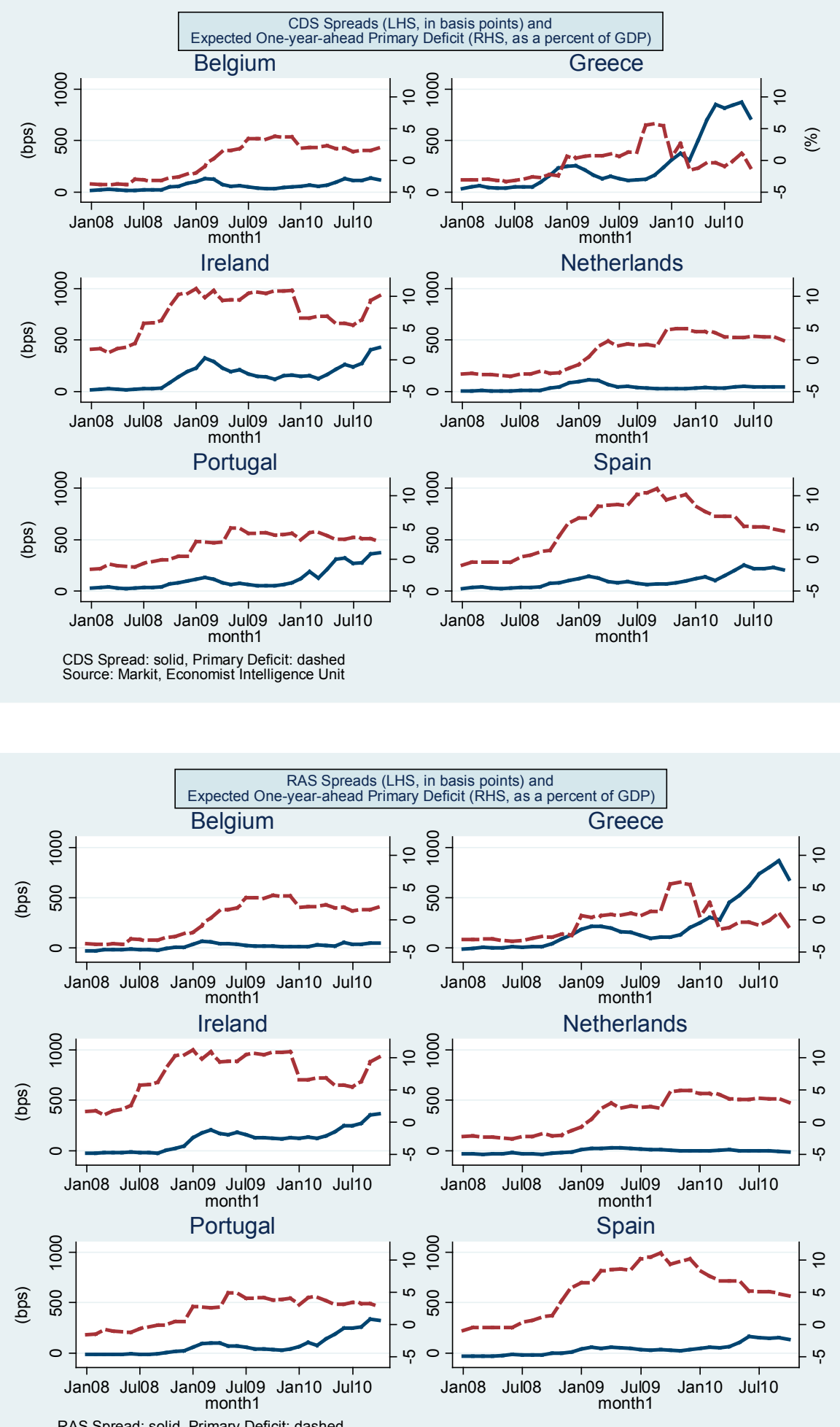

RAS Spread: solid, Primary Deficit: dashed

Source: Datastream, Economist intelligence Unit 
Table 1. Panel and Individual Unit Root Test Results on the Basis (CDS-RAS)

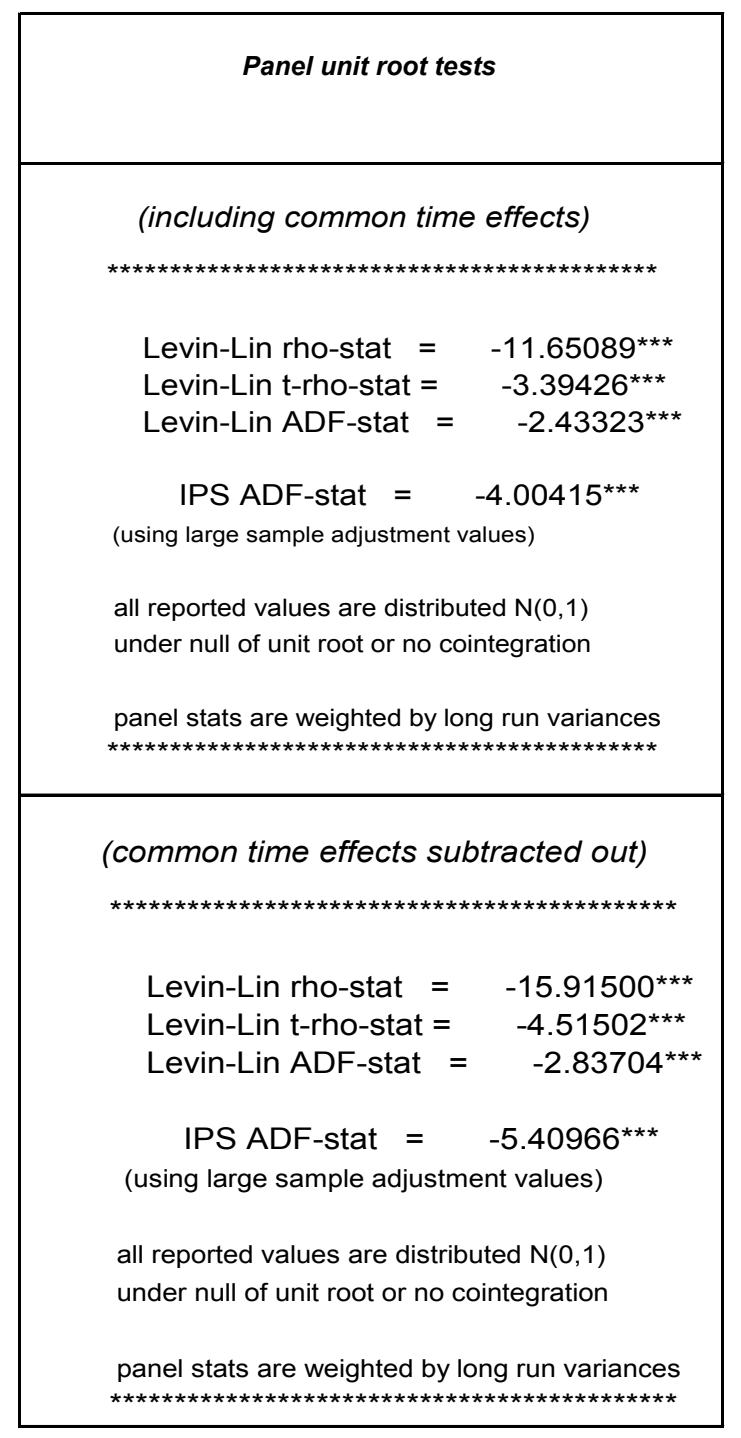

\begin{tabular}{|c|c|c|}
\hline Country & $\begin{array}{c}\text { ADF test } \\
\text { statistics on } \\
\text { the basis }\end{array}$ & Number of lags \\
\hline Australia & -2.426 & 2 \\
\hline Austria & -2.473 & 0 \\
\hline Belgium & -1.328 & 1 \\
\hline Denmark & -1.980 & 1 \\
\hline Finland & -2.001 & 1 \\
\hline France & -1.579 & 1 \\
\hline Germany & -2.359 & 0 \\
\hline Greece & $-3.236^{* *}$ & 0 \\
\hline Ireland & $-2.728^{*}$ & 0 \\
\hline Italy & $-2.948^{* *}$ & 0 \\
\hline Japan & 2.338 & 0 \\
\hline Netherlands & -1.886 & 1 \\
\hline Norway & -1.886 & 1 \\
\hline Portugal & $-2.641^{*}$ & 2 \\
\hline Spain & $-3.572^{* * *}$ & 0 \\
\hline Sweden & -1.880 & 0 \\
\hline U.K. & -2.155 & 0 \\
\hline U.S. & $-2.881^{* *}$ & 1 \\
\hline
\end{tabular}

Reading: ${ }^{*}{ }^{* *},{ }^{* * *}$ indicate rejection of the null hypothesis of a unit root at the $10 \%, 5 \%$ and $1 \%$ thresholds, respectively. All panel unit root tests allow for heterogeneity under the alternative hypothesis, i.e. do not require that the parameter of interest is the same for all members of the panel. Lag lengths (not reported for panels) have been obtained by a step-down procedure. 
Table 2. Individual Cointegration Test and Error-correction Model Estimation Results for CDS and RAS Spreads

\begin{tabular}{|c|c|c|c|c|c|c|c|}
\hline \multirow[t]{2}{*}{ Country } & \multirow[t]{2}{*}{ Trace test statistics } & \multirow{2}{*}{$\begin{array}{c}\text { Number } \\
\text { of lags } \\
\text { in VAR }\end{array}$} & \multirow{2}{*}{$\begin{array}{c}\text { Slope } \\
\text { coefficient of } \\
\text { the } \\
\text { cointegrating } \\
\text { vector }\end{array}$} & \multirow{2}{*}{$\begin{array}{l}\text { Deterministic } \\
\text { term }\end{array}$} & \multicolumn{2}{|c|}{$\begin{array}{l}\text { Speed of adjustment } \\
\text { coefficients }\end{array}$} & \multirow[t]{2}{*}{ Interpretation } \\
\hline & & & & & $\alpha_{R A S}$ & $\alpha_{C D S}$ & \\
\hline Australia & $23.932^{*}$ & 3 & $0.349^{* * *}$ & $\begin{array}{l}\text { Restricted linear } \\
\text { trend }\end{array}$ & $-0.075^{\star * \star}$ & $0.025^{\star *}$ & Very distorted arbitrage relationship \\
\hline Austria & $22.409^{* *}$ & 1 & $0.540^{* \star *}$ & \begin{tabular}{c|}
$\begin{array}{c}\text { Restricted } \\
\text { constant }\end{array}$ \\
\end{tabular} & $-0.032^{\star \star \star}$ & -0.012 & $\begin{array}{l}\text { RAS spreads adjust in case of deviation from the long-run equilibrium } \\
\text { relationship }\end{array}$ \\
\hline Belgium & $14.432^{*}$ & 1 & $0.495^{\star \star \star}$ & $\begin{array}{l}\text { Unrestricted } \\
\text { constant }\end{array}$ & $-0.033^{* \star *}$ & -0.012 & $\begin{array}{l}\text { RAS spreads adjust in case of deviation from the long-run equilibrium } \\
\text { relationship }\end{array}$ \\
\hline Denmark & $25.440^{\star * \star}$ & 1 & -0.100 & $\begin{array}{c}\text { Restricted } \\
\text { constant }\end{array}$ & $-0.047^{\star \star *}$ & $-0.011^{* *}$ & $\begin{array}{l}\text { RAS spreads adjust in case of deviation from the long-run equilibrium } \\
\text { relationship }\end{array}$ \\
\hline Finland & $25.994^{* * *}$ & 1 & $0.787^{\star \star \star}$ & $\begin{array}{c}\text { Restricted } \\
\text { constant }\end{array}$ & $-0.023^{\star \star *}$ & $-0.010^{\star *}$ & $\begin{array}{l}\text { RAS spreads adjust in case of deviation from the long-run equilibrium } \\
\text { relationship }\end{array}$ \\
\hline France & 15.536 & 4 & - & - & - & - & No ECM \\
\hline Germany & 11.789 & 1 & - & - & - & - & No ECM \\
\hline Greece & $17.351^{* *}$ & 1 & $0.921^{* * *}$ & $\begin{array}{l}\text { Unrestricted } \\
\text { constant }\end{array}$ & $-0.046^{\star * *}$ & -0.012 & $\begin{array}{l}\text { RAS spreads adjust in case of deviation from the long-run equilibrium } \\
\text { relationship }\end{array}$ \\
\hline Ireland & $31.068^{* * *}$ & 1 & $0.744^{* \star *}$ & $\begin{array}{c}\text { Restricted linear } \\
\text { trend }\end{array}$ & $-0.062^{\star \star \star}$ & $-0.036^{\star \star *}$ & $\begin{array}{l}\text { RAS and CDS spreads adjust in case of deviation from the long-run } \\
\text { equilibrium relationship }\end{array}$ \\
\hline Italy & $18.533^{*}$ & 1 & $0.714^{\star \star *}$ & \begin{tabular}{c|}
$\begin{array}{c}\text { Restricted } \\
\text { constant }\end{array}$ \\
\end{tabular} & $-0.029^{\star * *}$ & 0.001 & $\begin{array}{l}\text { RAS spreads adjust in case of deviation from the long-run equilibrium } \\
\text { relationship }\end{array}$ \\
\hline Japan & $23.668^{* * *}$ & 1 & $0.229^{\star \star *}$ & $\begin{array}{l}\text { Restricted } \\
\text { constant }\end{array}$ & $-0.042^{\star \star *}$ & 0.021 & $\begin{array}{l}\text { RAS spreads adjust in case of deviation from the long-run equilibrium } \\
\text { relationship }\end{array}$ \\
\hline Netherlands & $20.065^{\star}$ & 1 & $0.467^{* * *}$ & $\begin{array}{l}\text { Restricted } \\
\text { constant }\end{array}$ & $-0.024^{\star \star *}$ & $-0.011^{* *}$ & $\begin{array}{l}\text { RAS spreads adjust in case of deviation from the long-run equilibrium } \\
\text { relationship }\end{array}$ \\
\hline Norway & $25.658^{* *}$ & 1 & $1.234^{\star \star *}$ & $\begin{array}{c}\text { Restricted } \\
\text { constant }\end{array}$ & $-0.040^{* * *}$ & $0.009^{* *}$ & Very distorted arbitrage relationship \\
\hline Portugal & 13.287 & 1 & - & - & - & - & No ECM \\
\hline Spain & $19.510^{* * *}$ & 3 & $0.865^{\star * *}$ & $\begin{array}{l}\text { Unrestricted } \\
\text { constant }\end{array}$ & $-0.028^{\star *}$ & 0.017 & $\begin{array}{l}\text { RAS spreads adjust in case of deviation from the long-run equilibrium } \\
\text { relationship }\end{array}$ \\
\hline Sweden & 7.211 & 2 & - & - & - & - & No ECM \\
\hline U.K. & $25.390^{*}$ & 1 & $0.199^{* *}$ & $\begin{array}{c}\text { Restricted linear } \\
\text { trend }\end{array}$ & $-0.027^{\star \star *}$ & $0.028^{* * *}$ & Very distorted arbitrage relationship \\
\hline U.S. & $65.204^{* * *}$ & 1 & $0.390^{* * *}$ & $\begin{array}{c}\text { Restricted linear } \\
\text { trend }\end{array}$ & $-0.149^{* * *}$ & 0.006 & $\begin{array}{l}\text { RAS spreads adjust in case of deviation from the long-run equilibrium } \\
\text { relationship }\end{array}$ \\
\hline
\end{tabular}

Reading: ${ }^{*},{ }^{* *},{ }^{* *}$ indicate significance at the $10 \%, 5 \%$ and $1 \%$ thresholds, respectively. In the trace tests, the null hypothesis is that the number of cointegrating vectors is zero against the alternative that there is one cointegrating vector. 
Table 3. CDS Spreads Regressions

VARIABLES

(1)

(2)

(3)

(4)

(5)

Domestic fiscal variables

Lag $\triangle . C D S$

$\Delta$.Expected_Deficit ( $t$ )

$\Delta$.Debt $(t-1)$

$\Delta$.Expected_Growth $(t+1)$

$\begin{array}{ccccc}0.205^{* * *} & 0.161^{* *} & 0.174^{* * *} & 0.177^{* * *} & 0.121^{*} \\ 3.495^{* * *} & 2.857^{* *} & 2.879^{* * *} & 3.221^{* * *} & 3.350^{* * *} \\ -0.470 & -0.362 & -0.492 & -0.537 & -0.448 \\ -11.131^{* * *} & -7.656^{*} & -10.120^{* *} & -11.563^{* *} & -11.684^{*}\end{array}$

Domestic financial variables

$\Delta$. Short Term Rate

$\triangle$.Banks Stock Prices

$\begin{array}{cccc}-8.818^{* *} & -7.692^{* *} & -13.097^{* * *} & -7.821^{* *} \\ -86.153^{* * *} & -79.409^{* * *}-72.277^{* * *} & -47.624^{* * *}\end{array}$

\section{Global variables}

$\Delta$.Expected Global Growth $(t+1)$

$\triangle$ VIX

BStearns_dummy

Lehman_dummy

Greece_dummy

Greece_Program_dummy

$\begin{array}{ccc}9.358^{* * *} & 8.872^{* * *} & 7.390^{* * *} \\ 1.132^{* * *} & 1.127^{* * *} & 0.880^{* * *} \\ & 1.442 & -6.193^{* * *} \\ & -4.420 & -3.901 \\ 4.246^{* *} & -1.372 \\ 1.981 & 5.307\end{array}$

Large Scale Bond Prchases

FED_Bond_Purchases_Announcement

FED_Government_Bonds_Purchases

Central Banks_Government_Bonds_Purchases

$-86.153^{\star \star *}-79.409^{\star \star *}-72.277^{\star * *}-47.624^{\star \star \star}$

Constant

$1.268^{* * *}$

0.281

$1.104^{*}$

0.185

$7.323^{* * *}$

Observations

$714 \quad 714$

714

714

713

Number of countries

21

21

21

21

21

$R$-squared

\begin{tabular}{rlllll} 
within & 0.105 & 0.162 & 0.257 & 0.280 & 0.317 \\
between & 0.890 & 0.679 & 0.728 & 0.731 & 0.722 \\
ovrall & 0.123 & 0.175 & 0.268 & 0.291 & 0.325 \\
\hline
\end{tabular}

Note: Estimates are obtained using random effects with clustered standard errors using monthly data for the period January 2008 - October 2010 (a maximum of 34 observations per country). The dependent variable is the monthly change in the sovereign CDS spread. Lag $\triangle . C D S$ denotes the lag of the first difference of the sovereign CDS spread; other variables are described in the Data Appendix. 
Table 4. RAS Spreads Regressions

VARIABLES

(1)

(2)

(3)

(4)

(5)

\section{Domestic fiscal variables \\ Lag $\triangle$.RAS \\ $\triangle$.Expected_Deficit ( $t$ ) \\ $\Delta$.Debt $(t-1)$ \\ $\Delta$.Expected_Growth $(t+1)$}

Domestic financial variables

$\Delta$.Short Term Rate

$\triangle$.Banks Stock Prices

\section{Global variables}

$\Delta$. Expected Global Growth ( $t+1)$

$\triangle$.VIX

BStearns_dummy

Lehman_dummy

Greece_dummy

Greece_Program_dummy

\section{Large Scale Bond Prchases}

FED_Bond_Purchases_Announcement

FED_Government_Bonds_Purchases

Central Banks_Government_Bonds_Purchases

Constant

Observations

Number of countries

$R$-squared

$\begin{array}{ccccc}0.294^{* * *} & 0.288^{* * *} & 0.288^{* * *} & 0.280^{* * *} & 0.273^{* * *} \\ 1.739^{*} & 1.428 & 1.408 & 1.589 & 1.599 \\ -0.413 & -0.362 & -0.377 & -0.356 & -0.329 \\ -4.954^{* * *} & -2.824 & -3.372^{*} & -2.818 & -2.788\end{array}$

$-6.473^{\star \star *}-6.699^{\star * *}-7.735^{\star * *}-6.556^{\star * *}$

$-23.647^{\star * *}-23.974^{\star * *}-18.554^{\star *}-12.203$

$\begin{array}{ccc}1.866 & 2.260 & 2.042 \\ 0.101^{*} & 0.154^{* *} & 0.100 \\ & 2.838^{* *} & 1.058 \\ & 4.174^{* *} & 4.164^{* *} \\ & 6.797^{* * *} & 5.385^{\star * *} \\ & -8.982^{* *} & -8.271^{*}\end{array}$

$\begin{array}{cc}-8.719^{* * *} & -10.062^{* * *} \\ & -35.133^{* *} \\ & -0.936\end{array}$

$\begin{array}{ccccc}1.559^{* * *} & 1.004^{* *} & 1.115^{* *} & -1.990^{* *} & -0.271 \\ 646 & 646 & 646 & 646 & 645 \\ 19 & 19 & 19 & 19 & 19\end{array}$

\begin{tabular}{rccccc} 
within & 0.0770 & 0.100 & 0.102 & 0.131 & 0.136 \\
between & 0.982 & 0.963 & 0.962 & 0.962 & 0.972 \\
ovrall & 0.119 & 0.139 & 0.142 & 0.168 & 0.171 \\
\hline
\end{tabular}

Note: Estimates are obtained using random effects with clustered standard errors using monthly data for the period January 2008 - October 2010 (a maximum of 34 observations per country). The dependent variable is the monthly change in the sovereign CDS spread. Lag $\triangle . R A S$ denotes the lag of the first difference of the sovereign CDS spread; other variables are described in the Data Appendix. 
Table 5. CDS Spreads Regressions - Country Breakdown

\begin{tabular}{|c|c|c|c|}
\hline \multirow[b]{2}{*}{ VARIABLES } & \multicolumn{3}{|c|}{ CDS Spreads } \\
\hline & All countries & Large Advanced & $\begin{array}{c}\text { Selected Euro } \\
\text { Area }\end{array}$ \\
\hline \multicolumn{4}{|l|}{ Domestic fiscal variables } \\
\hline Lag $\triangle . C D S$ & $0.121^{*}$ & -0.001 & 0.012 \\
\hline$\Delta$.Expected_Deficit ( $t)$ & $3.350^{\star * *}$ & 2.292 & $4.002^{* * *}$ \\
\hline$\Delta . \operatorname{Debt}(t-1)$ & -0.448 & $-0.864^{* *}$ & -3.281 \\
\hline$\Delta . E x p e c t e d \_G r o w t h(t+1)$ & $-11.684^{*}$ & $-8.282^{* * *}$ & $-20.627^{\star *}$ \\
\hline \multicolumn{4}{|l|}{ Domestic financial variables } \\
\hline$\Delta$. Short Term Rate & $-7.821^{* *}$ & -1.616 & $-32.510^{\star \star *}$ \\
\hline$\Delta$. Banks Stock Prices & $-47.624^{* * *}$ & $-53.632^{* * *}$ & -57.757 \\
\hline \multicolumn{4}{|l|}{ Global variables } \\
\hline$\Delta$.Expected Global Growth $(t+1)$ & $7.390^{* * *}$ & $7.402^{\star * *}$ & $10.243^{* * *}$ \\
\hline$\triangle . V I X$ & $0.880^{\star * *}$ & $0.327^{\star * \star}$ & 0.369 \\
\hline BStearns_dummy & $-6.193^{* * *}$ & $-6.297^{* * *}$ & -5.547 \\
\hline Lehman_dummy & -3.901 & 0.403 & -9.849 \\
\hline Greece_dummy & -1.372 & $-4.845^{\star *}$ & 6.856 \\
\hline Greece_Program_dummy & 5.307 & 2.523 & 17.172 \\
\hline \multicolumn{4}{|l|}{ Large Scale Bond Prchases } \\
\hline FED_Bond_Purchases_Announcement & $-18.742^{\star * \star}$ & -1.797 & $-33.719^{\star \star \star}$ \\
\hline FED_Government_Bonds_Purchases & $-158.229^{\star * \star}$ & $-135.816^{\star * *}$ & $-184.867^{* * *}$ \\
\hline Central Banks_Government_Bonds_Purchases & 2.403 & $-11.852^{* \star \star}$ & 328.897 \\
\hline Constant & $7.323^{\star * *}$ & $6.466^{\star \star \star}$ & 5.274 \\
\hline Observations & 713 & 203 & 204 \\
\hline Number of countries & 21 & 6 & 6 \\
\hline \multicolumn{4}{|l|}{$R$-squared } \\
\hline within & 0.317 & 0.506 & 0.411 \\
\hline between & 0.722 & 0.064 & 0.303 \\
\hline ovrall & 0.325 & 0.503 & 0.408 \\
\hline
\end{tabular}

Note: Estimates are obtained using random effects with clustered standard errors using monthly data for the period January 2008 - October 2010 (a maximum of 34 observations per country). The dependent variable is the monthly change in the sovereign CDS spread. Lag $\triangle . C D S$ denotes the lag of the first difference of the sovereign CDS spread; other variables are described in the Data Appendix. Large advanced economies include Canada, France, Germany, Japan, United States and United Kingdom; the selected euro area ones countries are Belgium, Greece, Italy, Ireland, Portugal and Spain. 
Table 6. RAS Spreads Regressions--Country Breakdown

\begin{tabular}{|c|c|c|c|}
\hline \multirow[b]{2}{*}{ VARIABLES } & \multicolumn{3}{|c|}{ RAS Spreads } \\
\hline & All countries & Large Advanced & $\begin{array}{c}\text { Selected Euro } \\
\text { Area }\end{array}$ \\
\hline \multicolumn{4}{|l|}{ Domestic variables } \\
\hline Lag $\triangle . R A S$ & $0.273^{\star * *}$ & 0.020 & 0.136 \\
\hline$\Delta$. Expected_Deficit ( $t)$ & 1.599 & -0.142 & 3.142 \\
\hline$\Delta . \operatorname{Debt}(t-1)^{-}$ & -0.329 & 0.269 & -2.616 \\
\hline$\Delta$. Expected_Growth $(t+1)$ & -2.788 & $7.843^{* * *}$ & $-5.709^{\star \star \star}$ \\
\hline$\Delta$. Short Term Rate & $-6.556^{\star * *}$ & $-5.765^{\star * *}$ & $-17.473^{\star *}$ \\
\hline$\triangle$.Banks Stock Prices & -12.203 & $25.326^{* * *}$ & -16.018 \\
\hline \multicolumn{4}{|l|}{ Global and Financial variables } \\
\hline$\Delta$. Expected Global Growth $(t+1)$ & 2.042 & $-4.711^{*}$ & $7.353^{* * *}$ \\
\hline$\triangle . V I X$ & 0.100 & $-0.119^{*}$ & -0.169 \\
\hline BStearns_dummy & 1.058 & 0.113 & 3.888 \\
\hline Lehman_dummy & $4.164^{\star *}$ & $7.099^{* * *}$ & $8.837^{* *}$ \\
\hline Greece_dummy & $5.385^{\star * *}$ & 1.204 & $15.279^{*}$ \\
\hline Greece_Program_dummy & $-8.271^{*}$ & $-7.137^{\star * *}$ & 5.055 \\
\hline FED_Bond_Purchases_Announcement & $-10.062^{* * *}$ & $-13.413^{* * *}$ & -12.504 \\
\hline FED_Government_Bonds_Purchases & $-35.133^{* *}$ & -20.220 & $-110.379^{* * *}$ \\
\hline Central Banks_Government_Bonds_Purchases & -0.936 & $-13.999^{* * *}$ & 98.580 \\
\hline Constant & -0.271 & 0.043 & -0.966 \\
\hline Observations & 645 & 203 & 204 \\
\hline Number of countries & 19 & 6 & 6 \\
\hline \multicolumn{4}{|l|}{$R$-squared } \\
\hline within & 0.136 & 0.285 & 0.259 \\
\hline between & 0.972 & 0.00 & 0.628 \\
\hline ovrall & 0.171 & 0.280 & 0.262 \\
\hline
\end{tabular}

Note: Estimates are obtained using random effects with clustered standard errors using monthly data for the period January 2008 - October 2010 (a maximum of 34 observations per country). The dependent variable is the monthly change in the sovereign CDS spread. Lag D.RAS denotes the lag of the first difference of the sovereign CDS spread; other variables are described in the Data Appendix. Large advanced economies include Canada, France, Germany, Japan, United States and United Kingdom; the selected euro area ones countries are Belgium, Greece, Italy, Ireland, Portugal and Spain. 


\section{REFERENCES}

Aktug, E., Bae, Y. and G. Vasconcellos (2009):"“The Dynamics of Sovereign Credit Default Swap and Bond Markets: Empirical Evidence from the 2001-2007 Period," Lehigh University Working paper.

Ammer, J. and F. Cai (2007): "Sovereign CDS and Bond Pricing Dynamics in Emerging Markets: Does the Cheapest-to-Deliver Option Matter?," Federal Reserve Board Paper, No. 912, December.

Arora, V. B. and M. D. Cerisola (2001): "How Does U.S Monetary Policy Influence Economic Conditions in Emerging Markets?" IMF Staff Papers, Vol. 48, No. 3, pp. 474498.

Bai, J. and P. Collin-Dufresne (2010): "The Determinants of the CDS-Bond asis During the Financial Crisis of 2007-2009," mimeo.

Baldacci, E., S. Gupta and A. Mati (2008): "Is it (Still) Mostly Fiscal? Determinants of Sovereign Spreads in Emerging Markets," IMF Working Paper, No. 08/259.

Bank for International Settlements (2010a): "Triennial and semiannual surveys. Positions in global over-the-counter (OTC) derivatives markets at end-June 2010", Monetary and Economic Department.

Bank for International Settlements (2010b), Quarterly Review, June.

Blanco, R., Brennan, S. and I. Marsh (2003): “An Empirical Analysis of the Dynamic Relationship between Investment-grade Bonds and Credit Default Swaps", Bank of England Working Paper, No. 211.

Caceres, C., G. Vincenzo and M. Segoviano (2010): "Sovereign Spreads: Global Risk Aversion, Contagion or Fundamentals?” IMF Working Paper, No. 10/120.

Carboni, A. (2010), “Inside the Sovereign Credit Default Swap Market: Price Discovery, Announcements, Market Behavior and Corporate Sector, Mimeo.

Coudert, V. and M. Gex (2011): "The interactions between the Credit Default Swap and the Bond Markets in Financial Turmoil”, CEPII Working Paper, No. 11/02.

Chang-Lau, J. and Y. S. Kim (2004): "Equity Prices, Credit Default Swaps, and Bond Spreads in Emerging Markets", IMF Working Paper, No. 04/27.

Doh T. (2010): "The Efficacy of large-scale Asset Purchases at the Zero Lower Bound," Federal Reserve Bank of Kansas City Review, Second Quarter, pp. 5-34.

Dotz, N. (2007), “Time-varying Contributions by the Corporate Bond and CDS Markets to 
Credit Risk Price Discovery”, Deutsche Bundesbank Discussion Paper No. 08/2007.

Edwards, S. (1984): "LDC Foreign Borrowing and Default Risk: An Empirical Investigation, 1976-80," American Economic Review, Vol. 74, No. 4, pp. 726-34.

Engen, E. and G. Hubbard (2004): "Federal Government Debt and Interest Rates," NBER Working Paper, No. 10681.

European Central Bank (2009): “Credit Default Swaps and Counterparty Risk”, August.

Fontana, A. and M. Scheicher (2010) "An Analysis of Euro Area Sovereign CDS and Their Relation with Government Bonds," ECB Working Paper Series, No.12/2010.

Gagnon, J. E., Raskin, M. Remache, J. and B. P. Sack (2010): "Large-scale Asset Purchases by the Federal Reserve: did they work?" FRB of New York Staff Report, No. 441.

International Monetary Fund (2004) Global Financial Stability Report, Chapter II, Appendix 1, pp. 60-70.

(2006) Global Financial Stability Report, April. pp. 28-31.

Longstaff, F. A., J. Pan, L. H. Pedersen and K. J. Singleton (2007): "How Sovereign is Sovereign Credit Risk?" American Economic Journal: Macroeconomics, forthcoming.

Min, H. G. (1998): "Determinants of Emerging Market Bond Spreads: Evidence from Latin America," World Bank Policy Research Paper, No. 1899.

Neely, C. (2010): "The Large-Scale Asset Purchases Had Large International Effects," Federal Reserve Bank of St. Louis Working Paper Series, No. 2010-018B.

Norden, L. and M. Weber (2004): "The Comovement of Credit Default Swap, Bond and Stock Markets: An Empirical Analysis", CFS Working Paper No. 20.

Pan, J. and K. J. Singleton (2008): "Default and Recovery Implicit in the Term Structure of Sovereign CDS Spreads," The Journal of Finance, Vol. 63, No. 5, pp. 2345--2384.

Sgherri, S. and E. Zoli (2009): "Euro Area Sovereign Risk During the Crisis", IMF Working Paper, No. 09/222.

Zhu, H. (2004): "An Empirical Comparison of Credit Spreads between the Bond Market and the Credit Default Swap Market", BIS Working Paper No.160, August. 